\section{Conference on Metallic 'Creep'}

THE subject of creep and flow of metals at high temperature has become of increasing importance in view of the new methods of propulsion and the need for high-duty alloys which have arisen in the war years. At the same time, the pressure and urgency of the war-time problems have tended to concentrate research resources on the quick determination of experimental data and thus to restrict the time and attention which might have been devoted to the theoretical aspects of the subject. In an endeavour to offset this trend, and to obtain as much information and as wide a view as possible on the direction into which research on this subject should be guided, an all-day conference on metallic creep is being arranged, which is to be held at the Royal Society, on February 5. The programme opens with an introduction and a history of the subject by Prof. E. N. da C. Andrade. Other papers will deal with experimental studies of creep (H. J. Tapsell), physical theory (E. Orowan), metallurgical control of creep (Dr. N. Allen). The meeting will close with a general discussion, to be introduced by Sir Lawrence Bragg. It is hoped that, as a result of the conference, it will be possible to devise appropriate research projects and to share them between the various laboratories interested in 'creep', under a scheme which will provide close and effective inter-laboratory liaison. Attendance at the conference is by invitation only ; applications to attend should be addressed to Sir Charles Darwin, at the National Physical Laboratory, Teddington, Middlesex.

\section{Central Medical Library Bureau}

ThF Rockefeller Foundation has made an appropriation to the Royal Society of Medicine of a sum not exceeding $£ 61,725$, for capital expenditure and tapering maintenance over four years, to enable the Society to establish a Central Medical Library Bureau. The immediate function of this organisation is to assist in the rehabilitation of medical libraries on the Continent which have suffered through deprivation or devastation, and its long-term function the exchange of scientific medical information between individuals and institutions. The method to be employed initially is the use of microfilm ; but microfilm will only be supplied so long as the Society is satisfied that journals needed are unobtainable in their original form. A number of the best microfilm readers obtainable will be purchased by the Society and lent to participating institutions. The scheme approved by the Rockefeller Foundation envisages that while the work of rehabilitation is being carried on, interchange of information between medical libraries will be developed into a permanently functioning scheme which can continue to operate when rehabilitation is completed. Thus the more permanent function of the Central Medical Library Bureau will be gradually established, and the subscriptions of individuals and of associated libraries should enable the Society to continue the service without further assistance from the Rockefeller Foundation.

\section{French Psychologists During the War}

The secretary of the British Psychological Society, Prof. D. W. Harding, has received letters from two honorary fellows of the Society in France, from which the following extracts will be of interest. Prof. P. Janet writes : "Je vous remercie vivement de votre bonne lettre et je vous prie de remercier de ma part mes collègues de la société pour l'intérêt qu'ils veulent bien prendre à ma santè et à mon pauvre pays. Malgré bien des tristes deuils dans ma famille je me porte bien à 86 ans et je puis encore assez bien travailler." Prof. Georges Dumas writes : “Je n'ai pas souffert dans ma santé pendant ces six années d'épreuves mais je n'en ai pas moins 80 ans. Je n'ai pas besoin de vous dire avec quel sentiment de reconnaissance nous pensons tous à nos amis anglais qui nous ont si puissament aidés à nous sauver du plus grand danger qui ait menacé la France depuis le commencement de son histoire."

\section{Announcements}

A memorial service for the late Dr. E. F. Armstrong, who died on December 14, will be held on Thursday, January 17, at 2.30 p.m. at St. Martin's-in-theFields.

Sir I. M. Heilbron, professor of organic chemistry at the Imperial College of Science and Technology, London, has been awarded the Priestley Medal of the American Chemical Society, the highest honour in the Society's gift, which is awarded every three years for distinguished services to chemistry.

DR. W. J. S. NAUNTON, of Imperial Chemical Industries, Ltd., has been awarded the Colwyn Gold Medal of the Institution of the Rubber Industry for conspicuous services rendered to the rubber industry.

THe Council of the Geologists' Association has accepted a sum of money for the establishment of a fund to commemorate Henry Stopes, a pioneer in investigations concerning early man. The Fund, which is to be known as the Henry Stopes Memorial Fund, will provide for the triennial award of a bronze medal for work on the prehistory of man and his geological environment. The design and execution of the medal has been entrusted to Mr. E. R. Bevan.

A David Anderson-Berry Silver-gilt Medal, to. gether with a sum of money amounting to about $£ 100$, will be awarded in 1947 by the Royal Society of Edinburgh to the person who, in the opinion of the Council, has recently produced the best work on the therapeutical effect of $\mathbf{X}$-rays on human diseases. Applications for this prize, which may be based on both published and unpublished work and should be accompanied by copies of relevant papers, must be in the hands of the General Secretary, Royal Society of Edinburgh, 22 George Street, Edinburgh 2, by December 1, 1946.

A Jornt Committee on Metallurgical Education has been formed by the Councils of the Iron and Steel Institute, the Institution of Mining and Metallurgy, the Institute of British Foundrymen, the Institute of Metals and Institution of Metallurgists. The Committee will advise and co-ordinate the policy of these Councils on all matters concerning education in metallurgy, direct attention to the requirements of industry, advise those responsible for teaching and assist parents and masters in guiding boys in the choice of future careers. Inquiries should be addressed to the Secretary at 4, Grosvenor Gardens, London, S.W.1.

Erratum. In Nature of January 5, p. 6, the second reaction in column 1 is of course incorrect; it should read :

$$
{ }_{94}^{239} \mathrm{Pu} \rightarrow{ }_{92}^{235} \mathrm{U}+{ }_{2}^{4} \mathrm{He}+\text { energy. }
$$

